\title{
Variants of WDR36 in Cameroonian glaucoma patients
}

\author{
Fanny Mbacham ${ }^{1}$, Yannick Bilong ${ }^{1,2}$, Jean Paul Chedjou ${ }^{3,4}$, \\ Arlette Nomo ${ }^{1,2}$, Chantal Nanfack Ngoune ${ }^{1,2}$, Hermann \\ Dongmo $^{3,4}$, CalvinoTAH ${ }^{4}$, Jean-Claude Katte ${ }^{1,5}$, Wilfred \\ Mbacham ${ }^{1,3,4}$, Eugene Sobngw $\left.\right|^{1,3,5}$ and Assumpta Lucienne \\ Bella ${ }^{1,2 *}$
}

${ }^{1}$ Faculty of Medicine and Biomedical Sciences, University of Yaoundé I, Cameroon

${ }^{2}$ Ophthalmology Unit, Yaoundé Gynaeco-Obstetrics and Paediatric Hospital, Cameroon ${ }^{3}$ Biotechnology Center, University of Yaoundé I, Cameroon

${ }^{4}$ Faculty of Science, University of Yaoundé I, Cameroon

${ }^{5}$ National Obesity Centre and Endocrinology and Metabolic Diseases Unit, Yaoundé Central Hospital, Cameroon

Received: 11 November, 2020

Accepted: 10 December, 2020

Published: 11 December, 2020

*Corresponding author: Bella Assumpta Lucienne, MD, Professor, Department of Ophthalmology, Otorhinolaryngology and Stomatology, Yaoundé Gynaeco-Obstetric and Pediatric Hospital, Faculty of Medicine and Biomedical Sciences, University of Yaoundé I P.O Box 1937, Cameroon,

Email: assumptalucienne.bella@yahoo.com

Keywords: POAG; WDR36; SNP; Alul; Apol

https://www.peertechz.com

\section{Check for updates}

\begin{abstract}
Background: In Primary Open Angle Glaucoma (POAG), the most common form of glaucoma in people of African origin, it is established that retinal ganglion cells are lost due to apoptosis. Loss of WDR36 (OMIM 609669) function has been shown to result in activation of the p53 stress-response pathway, a key regulator of apoptosis. However, there is controversy surrounding its contribution in the pathogenesis of POAG. We aimed to establish an association between 3 WDR36 gene polymorphisms and POAG.
\end{abstract}

Methods: We assessed 798 glaucoma medical records and selected 209 POAG cases. A total of 26 POAG cases residing in Yaoundé completed the study and 19 controls were matched for age and gender. Dried blood spots on Whatman filter paper grade 3 were used for DNA extraction by the Chelex method. Polymerase Chain Reaction (PCR) was conducted with two sets of primers on rs1971050, rs10038177 and rs10038058 followed by Restriction Fragment Length Polymorphism (RFLP) using restriction enzymes Alul on rs1971050, rs10038177and Apol on rs10038058 to determine the genotypes.

Results: After digestion, the homozygous mutant form of rs 1971050 was evidenced in both groups of our study population T/T (100\%). The T and the A alleles were the most common alleles found in our study population and were not associated with POAG. Heterozygote and homozygote mutant genotypes were obtained in both groups for rs10038177 (POAG group C/T (7.7\%) and T/T (92.3\%) and in the control group C/T (10.5\%) and T/T (89.5\%)) and rs10038058 (G/A (11.5\%) and A/A (88.5\%) genotypes in the POAG group and in the control group G/A (10.5\%) and A/A (89.5\%)). These genotypes were not associated with Primary Open Angle Glaucoma (POAG).

Conclusion: Homozygous mutant genotypes of rs1971050, rs10038177 and rs10038058 may not be associated with the disease process of primary open angle glaucoma in Cameroon.

\section{Introduction}

Glaucoma is an optic neuropathy associated with structural damage of the optic nerve and visual dysfunction [1]. Globally, it is the leading cause of irreversible blindness. The number of persons estimated to be blind as a result of primary glaucoma (POAG) is 4.5 million, accounting for slightly more than $12 \%$ of all global blindness [2]. In Africa, glaucoma accounts for $15 \%$ of blindness with a higher prevalence than in other regions. The primary risk factors that are linked to the individual and 
the onset of the disease are high intraocular pressure, age $>40$ years and genetic predisposition. Primary open angle glaucoma, the most common form of glaucoma progresses frequently in people of African origin and its incidence rises with age $[2,3]$. Glaucoma may have an early onset in blacks and a more aggressive clinical course [4]. The key to beating blindness from glaucoma is early detection and treatment.

Biomarkers are defined by the Food and Drug Administration as an anatomic, physiologic, biochemical or molecular parameter associated with the presence and severity of certain disease states [5]. Identifying disease-associated alleles in different population traits worldwide serves to understand their contribution to the pathogenesis of POAG, as an opportunity for large-scale meta-analysis of GWAS on glaucoma, to inform clinical trials with patient selection, to enrich the study population, to determine treatment effect and detect changes early. Although there is no ideal biomarker, some of the benefits of integrating biomarkers into clinical disease management include: early detection of disease, severity prediction, progression and response to treatment. Identifying these biomarkers worldwide will serve as a push to identify their biochemical pathways and molecular significance in optic nerve damage.

To date 29 loci have been linked to POAG but the roles of only three genes have been identified in these loci. These are: Myocyclin (MYOC, OMIM 601652)), Optineurin (OPTN, OMIM 602432), and WD repeat domain 36 (WDR36, OMIM 609669). Cytochrome P450, family I, subfamily B, polypeptide I (GSMTMI) and Neurotrophin (NTF4) have been fairly identified [6]. OPTN and MYOC have been shown to be high penetrance glaucoma causing genes. There is however great controversy among experts about the contribution of WDR36 and its variants in the pathogenesis of glaucoma. Unlike the original reports from Monemi, et al. 2005 [7] on the role of WDR36, many others followed, which failed to replicate the original studies in which the above genes were presented as glaucoma-causing genes. Data is currently inconclusive.

\section{Objectives}

The purpose of this study was to evaluate the association between POAG in a Cameroonian population and 3 Single Nucleotide Polymorphisms (SNPs) in the WDR36 genomic region.

\section{Material and methods}

\section{Study population}

This was a pilot case-control study over a period of 10 months (August 2018 - May 2019). Our study sample was made up of two groups. The first group with participants retained from health record booklet reviews of those with primary open angle glaucoma according to the following criteria: age 40 years or more, living with primary open angle glaucoma for at least 5 years or recently diagnosed with terminal stage. The control group was made up of participants selected during outpatient clinic consultations matched according to age, without any form of glaucoma, no family history of glaucoma or ocular hypertension, IOP $<20 \mathrm{mmHg}$, difference in IOP in both eyes not more than $3 \mathrm{mmHg}$.

Sample collection and DNA extraction: Participants retained presented themselves early in the morning by appointment at the Ophthalmology unit of the Yaoundé Gynaeco-Obstetric and Paediatric Hospital. Upon arrival, for each participant, we measured far and near visual acuity in both eyes using the tumbling " $E$ " eye chart and the Jaeger chart respectively. IOP was measured for both eyes using the air puff tonometer and capillary blood glucose levels were obtained using a blood glucose meter CERA-CHEK 1 Code (Model: G400) GREEN CROSS MEDIS Corps). Allfindings were recorded on the data sheet. Blood samples collected from participants were spotted on Whatman filter paper grade 3 and dried, for genomic analysis using the Chelex 100 method [8]. The resultant DNA extracts were stored at $-20{ }^{\circ} \mathrm{C}$ for PCR analysis.

\section{Molecular genotyping}

The WDR36single nucleotide gene polymorphisms; rs1971050, rs10038177 and rs10038058were amplified using the following primers respectively: F 5' - GCCTCTCATTTATTTTATTTCTCAAGG - 3' and R 5' - CCTCTGATACAGGGGACCAACTG -3'; F 5' - GCCTCTCATTTATTTTATTTCTCAAGG - 3' and R 5' - CCTCTGATACAGGGGACCAACTG - 3'; F 5' - GAGGTGAAGAGCAATTGGGTTTCTC and R 5' - GCAGTGTCAGGAAAGACACTGTACC - 3'. Mookerherjee, et al. 2011 (41). The Master Mix was prepared in a $1.5 \mathrm{ml}$ tube according to the number of samples and spun in the centrifuge. Each PCR was carried out in a total volume of $22 \mu \mathrm{l}$ and the reaction medium was composed of $18.25 \mu$ l Nuclease free water (NFW), $2.5 \mu$ lbuffer (10X thermopol buffer), 10mM dNTPs ( $200 \mu \mathrm{M}$ of each deoxyribonucleotide), (0.25 $\mu \mathrm{l}) \mu \mathrm{Mof}$ each primer, (0.25 $\mu \mathrm{l}) \mathrm{U} / \mu \mathrm{lof}$ Taq DNA polymerase and $3 \mu$ l of DNA. The amplification programs previously recorded in the thermocycler ( $\mathrm{T} 3$ thermal cycler, Biometra, UK) proceeded as follows for the NAT2 gene amplification: The amplification program previously recorded in the thermocycler ( $\mathrm{T} 3$ thermal cycler (Biometra, UK)) proceeded as follows: the pre-denaturation is carried out at $95^{\circ} \mathrm{C}$ for 4 minutes followed by 35 amplification cycles. Each cycle was a succession of denaturation at $95^{\circ} \mathrm{C}$ for 30 seconds, annealing at $60^{\circ} \mathrm{C}$ for rs1971050; at $62^{\circ} \mathrm{C}$ for rs 10038177 and at $50^{\circ} \mathrm{C}$ for rs10038058 for 30 seconds each, elongation at $72^{\circ} \mathrm{C}$ for 30 seconds. The final extension, which comes at the end of these cycles, was carried out at $72^{\circ} \mathrm{C}$ for 4 minutes.WDR36gene SNP's were determined by restriction fragment length polymorphism (RFLP) in a volume of $12 \mu$ l containing the PCR water, $8.6 \mu \mathrm{l}$ buffer (10X buffer), $3.0 \mu$ l of BSA, either $0.4 \mu \mathrm{l}$ of AluI restriction enzyme for rs1971050; $0.4 \mu \mathrm{l}$ of AluI restriction enzyme for rs10038177; 0.4 $\mu \mathrm{A}$ ApoI restriction enzyme for rs10038058 and $8 \mu \mathrm{l}$ of WDR36 amplicon. The mixtures were then incubated at 37 ${ }^{\circ} \mathrm{C}$ overnight for rs1971050 and rs10038177 and at $50^{\circ} \mathrm{C}$ overnight for rs10038058.Digested and undigested fragments of each sample were separated on a $2 \%$ agarose gel stained with ethidium bromide.

\section{Classification of genotypes}

The WDR36SNP phenotypes were classified as; rs1971050 
(wild type $\mathrm{C} / \mathrm{C}$, heterozygote $\mathrm{C} / \mathrm{T}$, mutant $\mathrm{T} / \mathrm{T}$ ), rs10038177 (wild type $\mathrm{C} / \mathrm{C}$, heterozygote $\mathrm{C} / \mathrm{T}$, mutant $\mathrm{T} / \mathrm{T}$ ), rs10038058 (wild type G/G, heterozygote G/A, mutant A/A) as described by Mookherjee, et al. 2011 [9].

\section{Data analysis}

All data was entered and analyzed on SPSS version 25.0 (SPSS Inc., USA) statistical software and Microsoft Excel 16. The different genotypes and phenotypes of the SNPs in the study population were expressed as frequencies (\%). The association between rs1971050, rs10038177 and rs10038058 SNPs of WDR36 and POAG in the study population were assessed by Chi-square analysis. All p-values <0.05 were considered statistically significant on a $95 \%$ confidence interval.

\section{Ethical approval}

The Institutional Ethics Committee for Research in Human Health (CIERSH)approved this study under the ethical clearance document number 768/CIERSH/DM/18. Recruitment of participants was done by free will and all signed informed consent forms

\section{Results}

Characteristics of the population: In total we selected 45 participants, 26 cases and 19 controls. The ratio of women to men in the study population is approximately $1: 1$. The median [IQR] age of the study population was 58.0 [51.5-61.0] years Past history of high intraocular pressure $(83.3 \%)$ and family history of glaucoma (38.5\%) were both important risk factors for POAG. $15.4 \%$ participants in the POAG group had diabetes and $5.3 \%$ in the control group. The median [IQR] intraocular pressure amongst participants with primary open angle glaucoma was $17.75[13.76-22.28]$ and in the control group was $14[10.75-15.76]$, (Table 1). Corrected visual acuity was measured in 90 eyes ( 45 study participants) and 74 had a visual acuity more than 3/10. In the POAG group, 6 participants had low vision and 6 others were blind.

WDR36SNP characterization results: After digestion of rs1971050, only the $\mathrm{T}$ allele and the $\mathrm{T} / \mathrm{T}$ mutant genotype was found in our study population (Tables 2,3 ).

For rs10038177, the mutant heterozygote $(\mathrm{C} / \mathrm{T})$ and homozygote phenotypes $(\mathrm{T} / \mathrm{T})$ were found in our study population, with the mutant phenotype $(\mathrm{T} / \mathrm{T})$ being predominant in both the POAG group (92.3\%) and the control group $(89.5 \%)$ group. The heterozygote phenotypes were found in both groups at a frequency of $(7.7 \%)$ for POAG group and $(10.5 \%)$ for the control group (Tables 2,3$)$.

For rs10038058, the mutant heterozygote (G/A) and homozygote $(\mathrm{A} / \mathrm{A})$ phenotypes were found in our study population. There was a predominance in both the POAG group $(88.5 \%)$ and the control group $(89.5 \%)$ of the mutant homozygous phenotype (A/A). The heterozygote phenotype (G/A) was found in both groups at a frequency of (11.5\%) for POAG and (10.5\%) for the control group (Tables 2,3). Correlation results between WDR36 SNPs and POAG: All participants showed the homozygous mutation for rs1971050. Meanwhile, the heterozygote and homozygous mutant forms were obtained in the study population for rs10038177 and rs10038058. None of these expressed phenotypes showed a significant association with glaucoma $(\mathrm{p}-/, \mathrm{OR}=0.7$ and $\mathrm{OR}=0.9$ respectively) . There was no association between rs1971050,rs10038177 and rs10038058single nucleotide polymorphisms and the onset or progression of glaucoma (Table 4).

Table 1: Distribution of clinical data, history and evolution of POAG in POAG and Control groups.

\begin{tabular}{|c|c|c|c|c|c|}
\hline \multicolumn{2}{|c|}{ Characteristics } & $\begin{array}{l}\text { Total } \\
\text { n(\%) }\end{array}$ & $\begin{array}{c}\text { Control } \\
\mathrm{n}(\%)\end{array}$ & $\begin{array}{c}\text { POAG } \\
n(\%)\end{array}$ & p-value \\
\hline \multirow{4}{*}{$\begin{array}{l}\text { Risk } \\
\text { factors }\end{array}$} & $\begin{array}{l}\text { Past history of } \\
\text { high IOP }\end{array}$ & $20(46.5)$ & 0 & $20(83.3)$ & I \\
\hline & $\begin{array}{l}\text { Family history } \\
\text { Glaucoma }\end{array}$ & $11(24.4)$ & $1(5.3)$ & $10(38.5)$ & I \\
\hline & Diabetes & $5(11.1)$ & $1(5.3)$ & $4(15.4)$ & I \\
\hline & Hypertension & $10(22.2)$ & $4(21.1)$ & $6(23.1)$ & / \\
\hline \multirow[t]{3}{*}{$\begin{array}{l}\text { Medical } \\
\text { history }\end{array}$} & $\begin{array}{l}\text { Glaucoma } \\
\text { surgery }\end{array}$ & $6(13.3)$ & 0 & $6(23.1)$ & I \\
\hline & & $\begin{array}{c}\text { Intraocular } \\
\text { pressure } \mathrm{mmHg}\end{array}$ & & & \\
\hline & & Total & Control & POAG & \\
\hline \multicolumn{2}{|c|}{ IOP median[IQR] } & $\begin{array}{c}15.93[12.38- \\
19.31]\end{array}$ & $\begin{array}{c}14[10.75- \\
15.76]\end{array}$ & $\begin{array}{c}17.75[13.76- \\
22.28]\end{array}$ & \\
\hline
\end{tabular}

N: Study Population Size; \%: Percentage; POAG: Primary Open Angle Glaucoma; IOP Intraocular Pressure; IQR: Interquartile Range

Table 2: Allelic frequency of WDR36 SNPs in POAG and Control groups.

\begin{tabular}{|c|c|c|c|c|c|}
\hline SNPs & Allele & \begin{tabular}{|} 
Frequency in \\
Control \\
(no. of \\
chromosomes) \\
$n(\%)$
\end{tabular} & $\begin{array}{c}\text { Frequency in } \\
\text { POAG } \\
\text { (no. of } \\
\text { chromosomes) } \\
\text { n(\%) }\end{array}$ & $\begin{array}{c}\mathbf{p} \\
\text { value }\end{array}$ & $\begin{array}{c}\text { OR } \\
(95 \% \mathrm{Cl})\end{array}$ \\
\hline \multirow{2}{*}{$\begin{array}{c}\text { rs1971050 } \\
(\text { c.330+925C>T) }\end{array}$} & C & 0 & 0 & \multirow[b]{2}{*}{ / } & \multirow[b]{2}{*}{ / } \\
\hline & $\mathrm{T}$ & $19(100)$ & $26(100)$ & & \\
\hline \multirow{2}{*}{$\begin{array}{c}\text { rs10038177 } \\
(\text { c. } 710+30 C>T)\end{array}$} & C & $2(10.5)$ & $2(7.7)$ & \multirow[b]{2}{*}{ / } & \multirow{2}{*}{$1.4(0.2-11.0)$} \\
\hline & $\mathrm{T}$ & $19(100)$ & $26(100)$ & & \\
\hline \multirow{2}{*}{$\begin{array}{c}r s 10038058 \\
(c .1494+143 G>A)\end{array}$} & G & $2(10.5)$ & $3(11.5)$ & \multirow[b]{2}{*}{ I } & \multirow{2}{*}{$0.9(0.1-6.0)$} \\
\hline & A & $19(100)$ & $26(100)$ & & \\
\hline
\end{tabular}

C, T, G, A: Alleles; N: Study Population Size; \% : Percentage; POAG: Primary Open Angle Glaucoma; P: Significance; OR: Odds Ratio; Cl: Confidence Interval

Table 3: Genotypic frequency WDR36 SNPs in POAG and Control groups.

\begin{tabular}{|c|c|c|c|c|c|}
\hline SNPs & Genotype & $\begin{array}{l}\text { Frequency in } \\
\text { Control } \\
\text { (no. of } \\
\text { chromosomes) } \\
n(\%)\end{array}$ & $\begin{array}{c}\text { Frequency in } \\
\text { POAG } \\
\text { (no. of } \\
\text { chromosomes) } \\
n(\%)\end{array}$ & $\begin{array}{c}\mathbf{p} \\
\text { value }\end{array}$ & $\begin{array}{c}\text { OR } \\
(95 \% \mathrm{Cl})\end{array}$ \\
\hline \multirow{3}{*}{$\begin{array}{c}\text { rs1971050 } \\
\text { (c. } 330+925 \mathrm{C}>\mathrm{T})\end{array}$} & $\mathrm{C} / \mathrm{C}$ & 0 & 0 & \multirow{3}{*}{ / } & \multirow{3}{*}{ / } \\
\hline & $\mathrm{C} / \mathrm{T}$ & 0 & 0 & & \\
\hline & $T / T$ & 19(100) & $26(100)$ & & \\
\hline \multirow{3}{*}{$\begin{array}{c}\text { rs10038177 } \\
(c 710+30 C>T)\end{array}$} & $\mathrm{C} / \mathrm{C}$ & 0 & 0 & \multirow{3}{*}{ / } & \multirow{3}{*}{$0.7(0.01-5.5)$} \\
\hline & $\mathrm{C} / \mathrm{T}$ & $2(10.5)$ & $2(7.7)$ & & \\
\hline & $\mathrm{T} / \mathrm{T}$ & 17(89.5) & $24(92.3)$ & & \\
\hline \multirow{2}{*}{$\begin{array}{c}r s 10038058 \\
(c 1494+143 G>A)\end{array}$} & $\mathrm{G} / \mathrm{G}$ & 0 & 0 & \multirow[b]{2}{*}{ / } & \multirow[b]{2}{*}{$0.9(0.1-6.0)$} \\
\hline & $\mathrm{G} / \mathrm{A}$ & 2(10.5) & $3(11.5)$ & & \\
\hline
\end{tabular}

C/C: Wild Type Genotype; C/T: Heterozygote Genotype; T/T: Mutant Genotypes; A/A: Wild Type Genotype; G/A: Geterozygote Genotype, A/A: Mutant Genotypen -Study Population Size; \%: Percentage; POAG: Primary Open Angle Glaucoma; P. Significance; OR: Odds Ratio; Cl: Confidence Interval 
Table 4: Association between POAG group and Control group with SNPs of WDR36.

\begin{tabular}{|c|c|c|c|c|c|}
\hline SNP & Phenotype & $\begin{array}{c}\text { Control } \\
\mathbf{n}(\%)\end{array}$ & $\begin{array}{c}\text { POAG } \\
n(\%)\end{array}$ & p value & OR $(95 \% \mathrm{Cl})$ \\
\hline rs1971050 & Mutant & 19(100) & $26(100)$ & / & / \\
\hline \multirow{2}{*}{ rs10038177 } & Mutant & $17(89.5)$ & $24(92.3)$ & \multirow[b]{2}{*}{1} & \multirow[b]{2}{*}{$0.7(0.09-5.5)$} \\
\hline & Heterozygote & $2(10.5)$ & $2(7.7)$ & & \\
\hline \multirow{2}{*}{ rs10038058 } & Mutant & 17(89.5) & $23(88.5)$ & \multirow[b]{2}{*}{ 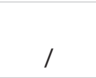 } & \multirow[b]{2}{*}{$0.9(0.1-6.0)$} \\
\hline & Heterozygote & $2(10.5)$ & $3(11.5)$ & & \\
\hline
\end{tabular}

N: Study Population Size; \%: Percentage; POAG: Primary Open Angle Glaucoma; $P$ : Significance; OR: Odds Ratio; Cl: Confidence Interval

\section{Discussion}

Data and information gotten on the distribution of genetic polymorphism in the population is essential to understand inter-individual differences in disease risk. Amongst the various types of glaucoma that exist, POAG has been shown to be the most common form in black African populations.

Our data showed an important family history of glaucoma $(38.5 \%)$ in the POAG group highlighting the contribution of genetics to the pathogenesis of the disease in this population.

WDR36 located at the GLC1G region was initially reported in an American family of Dutch ancestry with POAG and was later on shown not to be associated with glaucoma in an Australian population [10,11]. Monemi, et al. 2005 provided more evidence for a glaucoma-causing gene in this region [7]. A separate study by Hauser et al., 2006 showed more than 30 sequence variants in WDR36 and demonstrated its role as a modifier gene in POAG due to its association with greater clinical severity [12].

Our study assessed three SNPs rs1971050, rs10038177 and rs10038058 of WDR36 in a sample of participants with POAG matched to controls. After digestion, these SNPs either show the wild type (initial, non mutated form of the allele of that gene), the heterozygous mutant form (change in one allele) or the homozygous mutant form (change in both alleles). The homozygous mutant form (T/T) was observed for rs1971050 and the heterozygous and the homozygous mutations were observed for rs10038177 (heterozygote $\mathrm{C} / \mathrm{T}$, mutant $\mathrm{T} / \mathrm{T}$ ) and rs10038058 (heterozygote G/A, mutant A/A). Thus, The T and the $A$ alleles were the most common alleles found in our study population in both groups. Dissimilar to our findings, a study carried out by Fan BJ et al., 2009 in Chinese patients showed that the T-allele of rs10038177 was significantly associated with POAG [13]. Our study was underpowered to replicate these findings because of our sample size. This study was further limited by the selection of candidate genes and the selection of SNPs within each locus. Many other genes/loci have been shown to be associated with POAG, but they were not evaluated in this study. A meta-analysis carried out by Ke Liu, et al. 2017 found no association between rs10038177 (one of the most investigated polymorphisms of WDR36 in literature) and POAG [14]. Meanwhile, Mookhergee, et al. 2011 in an East Indian population proposed a possible association between rs10038177 and high-tension glaucoma cases [9] and Adelah, et al. 2016 in an Iraqi population, showed that the $\mathrm{T} / \mathrm{T}$ genotype of rs10038177 significantly raised the risk of POAG by two folds and none of the genotypes of rs1971050 was significantly associated with POAG [15]. Different genetic structures among different populations may be responsible for some of the conflicting results reported in the literature. Liu, et al. 2013 in their findings from a much larger association study of glaucoma in populations of African ancestry, concluded that genetic associations for POAG found in Caucasian populations play a smaller role in African POAG [16].

The results of this study add to the evidence that the POAG genetic susceptibility alleles found in other populations like Chinese, East Indians and Iraqis $[9,10,12]$ may play a reduced role in populations of African ancestry underscoring the need for large genome-wide association studies in these populations.

The observations of this study can only be truly validated after similar studies are carried out in larger cohorts in the same population group.

\section{Conclusion}

This study was set out to establish polymorphisms of WDR36 in the study population that may favour POAG. Based on the results presented herein, we were able to demonstrate that the primary open angle glaucoma group and control group showed either the heterozygous or the homozygous mutant genotypes for all 3 SNPs. Correlation tests showed no significant association of SNPs rs1971050, rs10038177 and rs10038058 with POAG. Therefore, homozygous mutant genotypes of rs1971050, rs10038177 and rs10038058, SNPs of the WDR36 gene may not be associated with the disease process of primary open angle glaucoma in Cameroon.

\section{Acknowledgments}

The authors would like to thank all the staff of the Ophthalmology unit of the Yaoundé Gynaeco-Obstetric and Paediatric Hospital, the staff of the laboratory for Public Health Research Biotechnologies and all of the study participants. Professor Wilfred Fon Mbacham funded this work under the auspices of the laboratory for Public Health Research Biotechnologies at the Biotechnology Centre, University of Yaoundé I.

\section{References}

1. Global Vision Impairment Facts. IAPB. [cited 2018 Apr 14]. Link: https://bit.ly/37NqHB3

2. WHO (2018) Priority eye diseases. WHO. Link: https://bit.ly/3m3yuzJ

3. Ellong A, Ebana Mvogo C, Bella-Hiag AL, Nyouma Moune E, Ngosso A, et al. (2006) La prévalence des glaucomes dans une population de noirs camerounais. Cahiers Santé 16: 83-88. Link : https://bit.ly/3oE3eZU

4. Martin MJ, Summer A, Gold EB, Diamond EL (1985) Race and primary openangle glaucoma. Am J Ophthalmol 99: 383-387. Link: https://bit.ly/374xRkY

5. Katz R (2004) Biomarkers and Surrogate Markers: An FDA Perspective. Neuro Rx 1: 189-195. Link: https://bit.ly/2LpiLOP

6. Kumar S, Malik MA, Goswami S, Sihota R, Kaur J (2016) Candidate genes involved in the susceptibility of primary open angle glaucoma. Gene 577: 119131. Link: https://bit.ly/3qHKFpm 
7. Monemi S, Spaeth G, DaSilva A, Popinchalk S, Ilitchev E, et al. (2005) Identification of a novel adult-onset primary open-angle glaucoma (POAG) gene on 5q22.1. Hum Mol Genet 14: 725-733. Link: https://bit.ly/2JR3W7d

8. Plowe CV, Djimde A, Bouare M, Doumbo O, Wellems TE (1995) Pyrimethamine and proguanil resistance-conferring mutations in Plasmodium falciparum dihydrofolate reductase: Polymerase chain reaction methods for surveillance in Africa. Am J Trop Med Hyg 52: 565-568. Link: https://bit.ly/373gtgD

9. Mookherjee S, Chakraborty S, Vishal M, Banerjee D, Sen A, et al. (2011) WDR36 variants in East Indian primary open-angle glaucoma patients. Mol Vis 17: 2618. Link: https://bit.ly/3oyWfkE

10. Kramer PL, Samples JR, Schilling K (2004) Mapping the GLC1G locus for primary open-angle glaucoma (POAG) in an Oregon family of Dutch origin (abstract). Am J Hum Genet 75: 1914.

11. Hewitt AW, Dimasi DP, Mackey DA, Craig JE (2006) A Glaucoma Case-control Study of the WDR36 Gene D658G Sequence Variant. Am J Ophthalmol 142 324-325. Link: https://bit.ly/2JPHNWU
12. Hauser MA, Allingham RR, Linkroum K, Wang J, LaRocque-Abramson K, et al. (2006) Distribution of WDR36 DNA Sequence Variants in Patients with Primary Open-Angle Glaucoma. Invest Ophthalmol Vis Sci 47: 2542-2546. Link: https://bit.ly/36ZM8Q1

13. Fan BJ, Wang DY, Cheng CY, Ko WC, Lam SC, et al. (2009) Different WDR36 mutation pattern in Chinese patients with primary open-angle glaucoma. Mol Vis 15: 646-653. Link: https://bit.ly/37P4J0p

14. Liu K, He W, Zhao J, Zeng Y, Cheng H (2017) Association of WDR36 polymorphisms with primary open angle glaucoma: A systematic review and meta-analysis. Medicine (Baltimore) 96: e7291. Link: https://bit.ly/370TZNa

15. Adelah AT, Hamza JM, Majid KH, Hayder MA (2016) Two Variants of WDR36 Genes in Primary Open Angle Glaucoma. EC Ophthalmology 3: 352-358. Link: https://bit.ly/3mamOLK

16. Liu Y, Hauser MA, Akafo SK, Qin X, Miura S, et al. (2013) Investigation of known geneticriskfactorsforprimaryopenangleglaucomaintwopopulations of African ancestry. Invest Ophthalmol Vis Sci 54: 6248-6254. Link: https://bit.ly/372vBL4
Discover a bigger Impact and Visibility of your article publication with Peertechz Publications

\section{Highlights}

* Signatory publisher of ORCID

* Signatory Publisher of DORA (San Francisco Declaration on Research Assessment)

* Articles archived in worlds' renowned service providers such as Portico, CNKI, AGRIS, TDNet, Base (Bielefeld University Library), CrossRef, Scilit, J-Gate etc.

* Journals indexed in ICMJE, SHERPA/ROMEO, Google Scholar etc.

* OAI-PMH (Open Archives Initiative Protocol for Metadata Harvesting)

* Dedicated Editorial Board for every journal

* Accurate and rapid peer-review process

* Increased citations of published articles through promotions

* Reduced timeline for article publication

Submit your articles and experience a new surge in publication services

(https://www.peertechz.com/submission).

Peertechz journals wishes everlasting success in your every endeavours.

Copyright: @ 2020 Mbacham F, et al. This is an open-access article distributed under the terms of the Creative Commons Attribution License, which permits unrestricted use, distribution, and r eproduction in any medium, provided the original author and source are credited.

Citation: Mbacham F, Bilong Y, Chedjou JP, Nomo A, Bella AL, et al. (2020) Variants of WDR36 in Cameroonian glaucoma patients . Biomed Sci Eng 6(1): 043-047. DOI: https://dx.doi.org/10.17352/abse.000021 